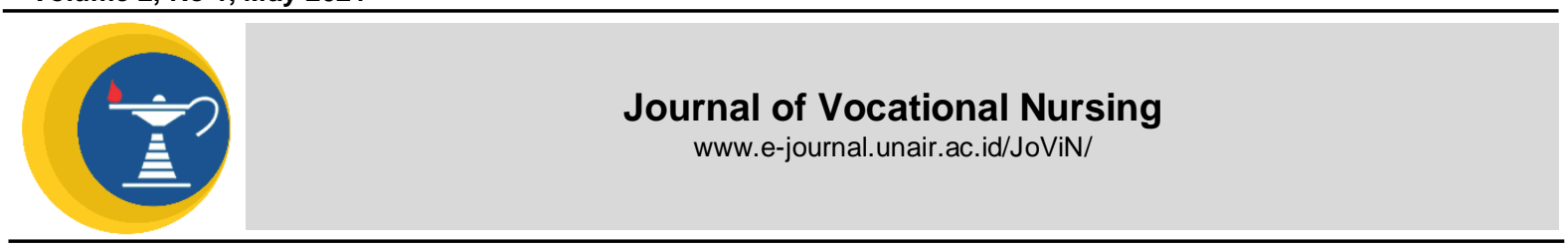

\title{
ACUTE PAIN NURSING CARE IN PATIENT WITH HEPATITIS B: A CASE STUDY
}

\author{
Fanni Okviasanti, Dia Ayu Anggraini, Aris Cahyo Purnomo \\ Faculty Of Vocational Studies, Universitas Airlangga
}

Research Report

\section{A BSTRACT}

Introduction: Severe pain in the upper right abdomen was commonly found in hepatitis $B$ patients. Hepatitis $B$ patients who experience pain take longer in the process of healing the disease than those who do not. Acute pain nursing care in hepatitis $B$ patients is still unknown. This study aimed to describe acute pain nursing care in patients with hepatitis $B$. Methods: This study used a case study design. Data collection from assessment to nursing evaluation was carried out in the internal ward of a governmental hospital in Lamongan on November 2019. The hepatitis B patient was observed or treated for at least three days. Data collection techniques used interviews, observation, and documentation. Data analysis was performed using narrative analysis. Results: Assessment of Mr. A with the main complaint felt by the patient was a pain in the upper right abdomen. The nursing diagnosis in Mr. A's case was found to be an actual diagnosis with priority being acute pain relate to physiological injury agents (D.0077). Nursing interventions at Mr. A were arranged based on priority diagnosis with acute pain using pharmacological techniques and nonpharmacological techniques, and antibiotics. Conclusion: The nursing problem of Mr. A was resolved after 72 hours of nursing intervention. The patient displayed a decreased level of pain with a pain scale of 2, decreased restlessness, no grimace, no protective attitude, and absence of insomnia.

\section{ARTICLE INFO}

Received May 18, 2021

Accepted May 31, 2021

Online May 31, 2021

*Correspondence:

Fanny Okviasanti

*Email:

fanni.okviasanti@vokasi.unair.ac.id

Keywords:

Acute Pain, Nursing Care, Hepatitis $B$, Case Study

\section{INTRODUCTION}

Hepatitis B is a clinical or pathological syndrome characterized by varying degrees of inflammation and necrosis of the liver, caused by the Hepatitis B virus (HBV) (Ismail et al., 2013). Hepatitis $B$ is a worldwide health issue that has potentially life-threatening. World Health Organization (WHO) estimates that in 2015, 257 million people lived with chronic hepatitis B infection, and a total of 887,000 people died, mainly due to cirrhosis and hepatocellular carcinoma (WHO, 2020). The prevalence of this disease is higher in the Western Pacific and African Region. In the Southeast Asia Region, Indonesia is in the second largest position after Myanmar (WHO, 2020). Indonesian Basic Health Research 2013 showed a national prevalence of hepatitis at $1.2 \%$. This condition increased two times higher than in 2007. Meanwhile, hepatitis B sufferers reached $21.8 \%$ of the total people with hepatitis
(Research and Development Board Ministry of Health Republic of Indonesia, 2013).

Many hepatitis B sufferers do not realize that they have been infected with the hepatitis B virus (HBV) (Soewignjo, 2008). It is commonly transmitted through bodily fluids such as semen, blood, and vaginal fluids. Most of the immunocompetent adults (>95\%) infected with HBV can spontaneously clear the infection. Patients may present with acute symptomatic disease or have asymptomatic infections identified during screening for HBV (Tripathi \& Mousa, 2021). Some of the physical conditions experienced by patients with Hepatitis B include fatigue, lack of appetite, nausea, vomiting, and joint pain (Soewignjo, 2008)

The clinical manifestations of HBV infection vary in both acute and chronic diseases. Patients may develop subclinical or anicteric hepatitis, icteric hepatitis, or less frequently fulminant hepatitis during acute 
infection. In chronic infection, patients may develop asymptomatic carriers, chronic hepatitis, cirrhosis, and hepatocellular carcinoma. Initial symptoms are nonspecific and may include anorexia, nausea, vomiting, stomach pain, and jaundice. In cases of severe liver damage, patients may develop jaundice, hepatic encephalopathy, ascites, gastrointestinal bleeding secondary to esophageal varices, coagulopathy, or infection. Diagnosis is based on serological blood tests in patients with suspected signs and symptoms and associated risk factors for viral hepatitis (Tripathi \& Mousa, 2021).

Severe pain in the upper right abdomen was commonly found in hepatitis B patients (Misna et al., 2018). The initial survey conducted in one of a governmental hospital in Lamongan also pointed out that most patients were suffering from hepatitis $B$ experience acute pain in the upper right abdomen. Pain symptoms arise from the stretching of the liver capsule (hepatomegaly), resulting in discomfort in the right upper quadrant. Hepatitis $B$ patients who experience pain take longer in the process of healing the disease than those who do not (Soewignjo, 2008). So far, acute pain nursing care in hepatitis B patients is still unknown. Therefore, this study aimed to describe acute pain nursing care in patients with hepatitis $B$

\section{MATERIALS AND METHODS}

This study used a case study design. A case study is a research to collect, organize, and analyze data about some instances concerning researchers' problems. The data is compared to one another while adhering to holistic and contextual principles (Luthfiyah, 2017). Data collection from assessment to nursing evaluation was carried out in the internal ward of a governmental hospital in Lamongan in November 2019. The hepatitis B patient was observed or treated for at least three days. Participant in this study was one hepatitis $B$ patient with acute pain who met the following criteria: $18-60$ years old and cooperative. If the patient has gone home before three days, it is necessary to replace another patient with the same case. Data collection techniques used interviews, observation, and documentation. Data analysis was performed using narrative analysis. In conducting this research, researchers were guided by ethical principles by giving informed consent and maintaining the confidentiality of patient data.

\section{RESULT}

Mr. A, a student of senior high school, aged 19 years old, presented to the emergency department with severe pain in the right upper abdomen. The pain was felt as stabbing, intermittent, and increases with activity. The pain started three days ago with a pain scale of 5. His vital signs were as follows: blood pressure $120 / 80 \mathrm{mmHg}$, pulse 88 beats/minute, respirations 20 breaths/minute, temperature $38,7 \mathrm{C}$. His consciousness was compos mentis. The patient was admitted to the ward immediately for further treatment.

Mr. A's past medical history stated that the patient was never admitted to the hospital before. The patient did not have chronically ill, allergies, nor a history of surgery. The patient also said that none of his immediate family had the same illness or had a previous history of hepatitis.

Physical examination of the abdominal area showed a flat shape, bowel sounds 14 times/minute, tenderness in the right upper quadrant, and felt an enlarged liver. Jaundice was seen on the patient's skin. Physical examination of other body parts is within normal limits.

Mr. A's laboratory results and normal range as follows: erythrocyte sedimentation rate (ESR) $11-23 \mathrm{~mm} /$ hour (10-22 $\mathrm{mm} /$ hour), alkaline phosphatase (ALP) 387 IU/L (61-232 $\mathrm{IU} / \mathrm{L})$, direct bilirubin $4,40 \mathrm{mg} \%(<0,25 \mathrm{mg} \%)$, total bilirubin $4,98 \mathrm{mg} / \mathrm{dl} \quad(0,36-0,97 \mathrm{mg} / \mathrm{dl})$, SGOT $330 \mathrm{U} / \mathrm{L}(<37 \mathrm{U} / \mathrm{L})$, SGPT $963 \mathrm{U} / \mathrm{L}(<39$ $\mathrm{U} / \mathrm{L}$ ), and HBsAg test positive.

Mr. A's medication includes aminoleban infusion $1000 \mathrm{ml} / 24$ hours, ceftriaxone injection twice daily, antrain injection three times daily, omeprazole three times daily, sanfuliq p.o three times daily, lesichol p.o three times daily, and urdafalk p.o three times daily.

Nursing diagnosis based on Standard Indonesian Nursing Diagnoses was acute pain (D.0077) associated with biological injury agents characterized by:

Subjective data: the patient complained of severe pain in the right upper abdomen. The pain was felt as stabbing, intermittent, and increases with activity. The pain started three days ago with a pain scale of 5 .

Objective data: tenderness in the right upper quadrant and felt an enlarged liver, jaundice, the patient seemed to grimace in pain, restless, there was an increase in the value of ESR, ALP, direct bilirubin, total bilirubin, SGOT, SGPT, and HBsAg test positive.

Nursing goals and outcomes: after 72 hours of nursing interventions, the patient will display a decreased pain level (L.08066) with the criteria as follows: a decrease of pain complain, restlessness, grimace, protective attitude, and insomnia. 
Nursing interventions: pain management (1.08238), which includes observations and identification of location, pain scale, and factors that reduce and worsen pain; provide of non-pharmacological technique for pain relief (relaxation technique); suggest to self-monitoring the pain; collaborate for giving the analgesic and other pharmacologic therapeutic for maintaining liver function.

Nursing implementations have been carried out following the planned interventions. Formative evaluations have been done in every single intervention, and summative evaluations were performed at the end of every shift duty. After 72 hours of nursing interventions, the patient displayed a decreased level of pain with a pain scale of 2 , decreased restlessness, no grimace, no protective attitude, and absence of insomnia.

\section{DISCUSSION}

This study aimed was to describe acute pain nursing care in patients with hepatitis $B$. Based on the nursing assessment in this study, patient was male and falls into a young adult age category. This is under previous studies, which stated that the prevalence of hepatitis B was primarily found in productive young men than in female (le et al., 2015). The high incidence in men is due to the consumption of alcohol and use drugs (Muttaqin, 2011).

Main complain of patient in this study was severe pain in the right upper abdomen. In addition, based on the physical examination results, it was found that the patient had a fever, jaundice, and palpable enlargement of the liver. The hepatitis B virus infection into the host body causes an inflammatory reaction in the liver cells, which causes pain. In addition, the inflammatory process also causes other reactions in the form of fever and enlargement (edema) of the liver. Jaundice occurs when there is too much bilirubin (the yellow pigment) in the blood. Bilirubin itself is formed when red blood cells are recycled. Bilirubin is carried by the blood to the liver, enters the body through the digestive tract, and is excreted through feces. In people with liver damage, bilirubin cannot be transferred through the liver so that it accumulates in the blood and is stored in the skin and eyes, causing the eyes and skin to turn yellow (Elizabeth, 2009; Muttaqin, 2011). The data on investigations show congruence with the description of infection and inflammation of the liver.

A suitable diagnosis between literature review and case review at the time of the assessment was only found data that was by the conditions experienced by the patient at the time of the assessment and following the complaints felt by the patient during the assessment where the main complaint was a pain when the diagnosis was taken it was adjusted to the complaints that were made. Acute pain associated with physiological injury agents most felt by patients who are more actual acute: Acute pain associated with physiological injury agents characterized by: The patient said he had pain in the upper right abdomen since three days ago. Pain like stabbing and pain scale 5 , the pain increases if made to move (Muttaqin, 2011).

After conducting an evaluation of the nursing care that has been given to Mr. A, the final results were that all problems that arise could be resolved on the third day according to the time specified in the action plan, with the result that the patient says the pain is reduced, the face looks relaxed. Besides, the pain response in patients is quite good. This is because the patient's condition fits the desired criteria.

\section{CONCLUSIONS}

Assessment of Mr. A with the main complaint felt by the patient was a pain in the upper right abdomen. It was characterized by enlargement of the liver, tenderness in the stomach, and increased direct bilirubin, total bilirubin, SGPT, and AST. The nursing diagnosis in Mr. A's case was found to be an actual diagnosis with priority being acute pain b.d physiological injury agents (D.0077). Nursing interventions at Mr. A were arranged based on priority diagnosis with acute pain using pharmacological techniques and nonpharmacological techniques, and antibiotics. In nursing implementation, there was conformity with the patient in the diagnosis of acute pain because the implementations were carried out under nursing interventions. In the evaluation stage, the nursing diagnosis at Mr. A was resolved within three days specified in the goal.

\section{REFERENCES}

Elizabeth, J. (2009). Buku Saku Patofisiologi. Edisi. Salemba Medika.

le, S. I., Turyadi, Sidarta, E., Sadhewa, A., Purnomo, G. A., Soedarmono, Y. S. M., Pattiiha, M. Z., Thedja, M. D., Harahap, A. R., \& Muljono, D. H. (2015). High prevalence of hepatitis $B$ virus infection in young adults in Ternate, Eastern Indonesia. American Journal of Tropical Medicine and Hygiene, 93(6), 1349-1355. https://doi.org/10.4269/ajtmh.15-0331

Ismail, A., Puhazhenthi, K., Sivakumar, J., Eapen, C., \& Kannangai, R. (2013). Molecular epidemiology and genetic characterization of hepatitis $B$ virus in the 
Indian Subcontinent. International Journal of Infection Desease, 20, 1-10.

Luthfiyah, M. F. (2017). Metodologi Penelitian : Penelitian Kualitatif, Tindakan Kelas \& Studi Kasus. CV Jejak.

Misna, R., Zein, U., \& Suroyo, B. (2018). Faktor Risiko Hepatitis B Pada Pasien di RSUD. Dr. Pirngadi Medan. Jurnal Kesehatan Global, $1(1), \quad 37$. https://doi.org/https://doi.org/10.33085/jk g.v1i1.3908

Muttaqin, A. (2011). Pengkajian Keperawatan Aplikasi Pada Praktik Klinik. Salemba Medika.

Research and Development Board Ministry of Health Republic of Indonesia. (2013). Basic Health Research 2013. https://doi.org/10.1007/s13398-0140173-7.2

Soewignjo. (2008). Hepatitis virus B, edisi ke-2. EGC.

Tripathi, \& Mousa, O. (2021). Hepatitis B. Treasure Island (FL). https://www.ncbi.nlm.nih.gov/books/NBK 555945/

WHO. (2020). Global Hepatitis Report. Geneva. World Health Organization. 